\title{
A new species of Phymaturus of the $P$. mallimaccii Group from the Andes of central Chile (Iguania: Liolaemidae)
}

\author{
Jaime Troncoso-Palacios ${ }^{1}$ and Damien Esquerré ${ }^{2}$ \\ 1 Programa de Fisiología y Biofísica, Facultad de Medicina, Universidad de Chile, Casilla 70005, Santiago, Chile. E-mail: \\ jtroncosopalacios@gmail.com. \\ 2 Evolution, Ecology and Genetics, Research School of Biology, The Australian National University, Canberra, ACT 0200, \\ Australia. E-mail: damien.esquerre@anu.edu.au.
}

\begin{abstract}
A new species of Phymaturus of the P. mallimaccii Group from the Andes of central Chile (Iguania: Liolaemidae). A new species of Phymaturus from the Provincia Mountain in the San Ramón Mountains in the Metropolitan Region of Chile is described. It is a member of the P. palluma Group and the P. mallimaccii subgroup. The new species can be distinguished from other members of the $P$. mallimaccii subgroup by having a highly fragmented subocular scale ( 4 or 5), a preocular scale that is smaller than the canthal, males having a olive dorsum with a diffuse pattern of light bands on the paravertebral fields and a light triangle between the shoulders, which has the apex of the triangle oriented toward the snout. The distribution of new species lies south of that of other members of the $P$. mallimaccii subgroup, from which it is completely isolated. The low abundance of the new species is noteworthy. Information about the natural history of the lizard is provided and some aspects of unnamed populations of Chilean Phymaturus are discussed.
\end{abstract}

Keywords: lizard, Phymaturus aguedae sp. nov., Provincia Mountain, species description.

\begin{abstract}
Resumen
Una nueva especie de Phymaturus del Grupo de P. mallimaccii de los Andes de Chile central (Iguania: Liolaemidae). Se describe una nueva especie de Phymaturus para el Cerro Provincia de la Sierra de San Ramón en la Región Metropolita de Chile. Esta pertenece al grupo de P. palluma y al subgrupo de $P$. mallimaccii. La nueva especie puede ser diferenciada de los otros miembros del subgrupo de $P$. mallimaccii por presentar una alta fragmentación de la escama subocular (4 o 5), la escama preocular más pequeña que la cantal, machos con color dorsal oliva y un patrón difuso de
\end{abstract}

Received 20 March 2014.

Accepted 20 May 2014.

Distributed August 2014 
bandas claras en los campos paravertebrales con un triángulo claro entre los hombros, el cual tiene el ápice orientado hacia el hocico. Esta nueva especie se distribuye más al sur que las otras especies del subgrupo de $P$. mallimaccii, de las cuales está completamente aislada. La baja abundancia de esta nueva especie es destacable. Se provee información sobre la historia natural del lagarto y se discuten ciertos aspectos sobre las poblaciones chilenas de Phymaturus que no han sido denominadas.

Palabras Clave: Cerro Provincia, descripción de especie, lagarto, Phymaturus aguedae sp. nov.

\begin{abstract}
Resumo
Uma nova espécie de Phymaturus do grupo P. mallimaccii dos Andes do Chile central (Iguania: Liolaemidae). Nós descrevemos uma nova espécie de Phymaturus da Província Mountain na Cordilheira San Ramón, Região Metropolitana, Chile. Essa nova espécie pertence ao grupo palluma e ao subgrupo de $P$. mallimaccii. No entanto, esse novo táxon possui características incomuns para o subgrupo de $P$. mallimaccii: grande fragmentação da escama subocular (4-5), escama pré-ocular sempre menor que a cantal, machos com coloração dorsal oliva e padrão difuso formado por faixas claras nas áreas paravertebrais e um triângulo claro entre os ombros, com a extremidade orientada em direção ao rostro. Além disso, essa nova espécie é completamente isolada e é a espécie do subgrupo de $P$. mallimaccii que se encontra distribuída mais ao sul. Também é notável sua baixa abundância. Adicionalmente, fornecemos informações sobre sua história natural e discutimos alguns aspectos de populações ainda não-classificadas de Phymaturus chilenos.
\end{abstract}

Palavras-chave: descrição de espécie, lagarto, Phymaturus aguedae sp. nov., Província Mountain.

\section{Introduction}

Lizards of the liolaemid genus Phymaturus are viviparous and herbivorous inhabitants of rocky places in the highlands of Chile and Argentina, and the Patagonian steppe in Argentina (Cei 1986). This genus currently contains 40 species (Uetz 2014) and its diversity has been underestimated historically; as recently as 1995 , only a total of 10 species was recognized (Etheridge 1995).

Etheridge (1995) subdivided Phymaturus into two groups - palluma and patagonicus. Based on the results of a phylogenetic analysis of morphological, skeletal and cytogenetic characters of Phymaturus, Lobo and Quinteros (2005) reported that the northern species of the $P$. palluma Group (that occur in northwestern San Juan, approximately north of $30^{\circ} 20^{\prime}$ S), represent a monophyletic subgroup, which was named the Puna Clade (Lobo et al. 2010). This northern clade was recovered again in an updated phylogeny by Lobo et al. (2012a), as well as in a phylogenetic analysis based on several nuclear and mitochondrial loci by which Morando et al. (2013), who named it the mallimaccii subgroup of the P. palluma Group. The males of members of this clade bear a "sprayed" dorsal pattern composed of small spots and lacking dorsal reticulation (Lobo et al. 2010, 2012a). To date, this clade contains 11 species: Phymaturus bibronii Guichenot, (1848); P. mallimaccii Cei, 1980; P. antofagastensis Pereyra, 1985; P. punae Cei, Etheridge \& Videla, 1985; P. alicahuense Núñez, Veloso, Espejo, Veloso, Cortés \& Araya, 2010; P. darwini Núñez, Veloso, Espejo, Veloso, Cortés \& Araya, 2010; P. laurenti Lobo, Abdala \& Valdecantos, 2010; P. extrilidus Lobo, Espinoza, Sanabria \& Quiroga, 2012; $P$. denotatus Lobo, Nenda \& Slodki, 2012; P. aguanegra Lobo, Laspiur \& Acosta, 2013; and P. williamsi Lobo, Laspiur \& Acosta, 2013. 


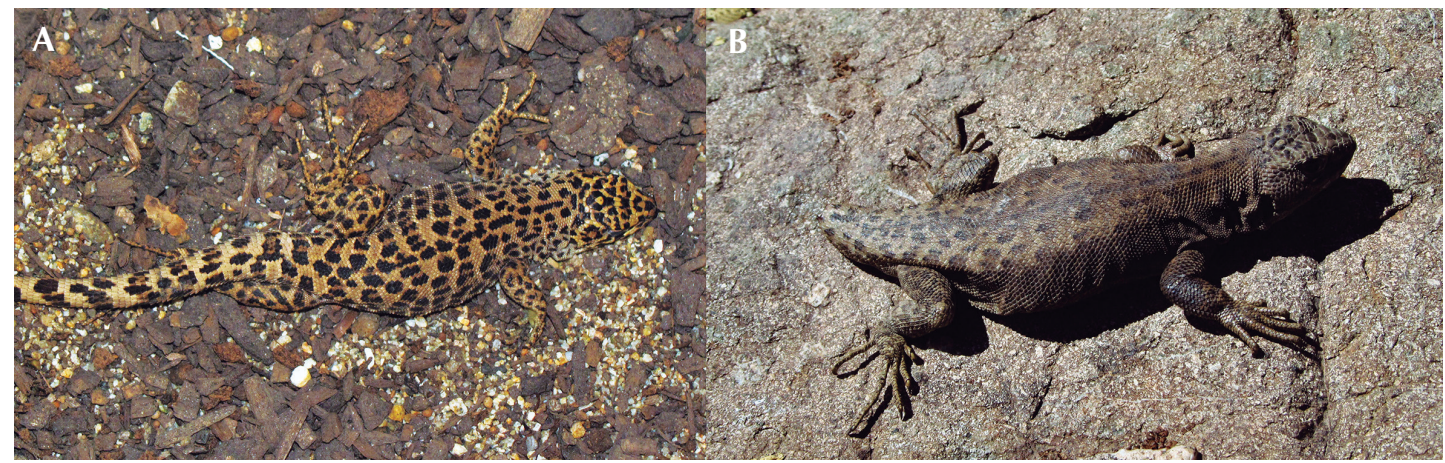

Figure 1. Species of Liolaemus endemic and co-distributed with Phymaturus in the highlands of the Metropolitan Region, Chile. (A) L. leopardinus. (B) L. ramonensis.

Several species of lizards that inhabit the highlands of central Chile are endemic. For example, four species of "leopard lizards," members of the Liolaemus leopardinus Group (Figure 1) occur on different, isolated mountains in the Metropolitan Region in Chile (PincheiraDonoso and Núñez 2005). In fact, L. leopardinus Müller and Hellmich, 1932, and Phymaturus darwini are syntopic and endemic to the highlands north of the Mapocho River (Núñez et al. 2010). However, no populations of Phymaturus have been recorded from the highlands south of the Mapocho River in the Metropolitan Region of Chile.

A population representing an undescribed species of Phymaturus was found in the San Ramon Highlands at elevations greater than $2680 \mathrm{~m}$, directly east of Santiago City during a fieldwork in 2009. Herein, we provide a diagnosis to distinguish it from all of the other species of the $P$. mallimaccii clade and discuss the status of other populations of Chilean Phymaturus.

\section{Materials and Methods}

The characters for description were taken from Etheridge (1995), Lobo and Quinteros (2005), and Lobo et al. (2010, 2012a). The description of colors in life is based on photographs of recently collected specimens. Lizards were collected with a noose and euthanized with sodium thiopental. Specimens SSUC Re 592-96 were fixed in 10\% formaldehyde (after extraction of the liver) and preserved in $70 \%$ ethanol. Specimens SSUC Re 588-89 were fixed in 96\% ethanol and preserved in $70 \%$ ethanol. All specimens were deposited in Colección de Flora y Fauna, Profesor Patricio Sánchez Reyes of the Pontificia Universidad Católica de Chile (SSUC). In addition, we examined specimens of all Chilean species of Phymaturus (Appendix I). Body measurements were taken with digital Vernier callipers $( \pm 0.02$ $\mathrm{mm}$ precision). Scales were observed with different magnifying lenses, and scalation and measurements were recorded the right side of the specimen, unless otherwise indicated. Museum codes are as follow: LCUC (Laboratorio de Citogenética, Facultad de Ciencias, Universidad de Chile); MNHN-CL (Museo Nacional de Historia Natural, Chile); and UNSJ (Colección Herpetólogica Universidad Nacional de San Juan). Data for the Argentinian species of Phymaturus were taken from the literature, and additional data not included in the description of P. williamsi (Lobo et al. 2013) were taken from digital photographs of topotypes supplied by A. Laspiur (UNSJ 285, 287, 289, 298, 299, 307, $311,313,318,320)$. 


\section{Results}

\section{Phymaturus aguedae sp. nov.}

(Figures 2 and 3)

Holotype.- SSUC Re 588. Adult male. Collected near the summit of the Provincia Mountain ( $33^{\circ} 25^{\prime}$ S, $70^{\circ} 26^{\prime}$ W), 2712 m, Metropolitan Region, Chile. Jaime Troncoso-Palacios and F. Meza colls. 22/11/2011.

Paratypes.-SSUC Re 592. One adult male. Near the summit of Provincia Mountain in the "Paso de Piedras", 2707 m. Jaime TroncosoPalacios and L. Negrete colls. November 2009. SSUC Re 595-96, two males and SSUC Re 593-94, two juveniles. Near the summit of Provincia Mountain, between 2683 and $2716 \mathrm{~m}$. Jaime Troncoso-Palacios and F. Díaz colls. January 2011. SSUC Re 589. Adult female. Near the summit of the Provincia Mountain, $2707 \mathrm{~m}$. Jaime Troncoso-Palacios and M. L. Carrevedo. 03/02/2012 (Figure 3).

Etymology.-The species is named after Agueda Palacios, the mother of JTP. The suggested English common name for this species is "Agueda's Rocky Lizard" and in Spanish, "Matuasto de Agueda".

Diagnosis.-Phymaturus aguedae sp. nov. belongs to the $P$. palluma Group because it has short, non-imbricate superciliary scales; 2 or 3 loreolabials between the posterior subocular and the supralabials; 4 or 5 subocular scales; and strongly spiny tail scales. Within the $P$. palluma Group, $P$. aguedae is a member of the mallimaccii clade, because it has a dorsal pattern formed by a homogeneous fine spotting ("spray") and lacks dark reticulation. It is the southernmost distributed species of the mallimaccii lineage.

Phymaturus aguedae can be distinguished from the Argentinian species of the mallimaccii clade (species listed ordered by date of description) as follows. Male $P$. mallimacci have a yellow dorsal color with small dispersed dark
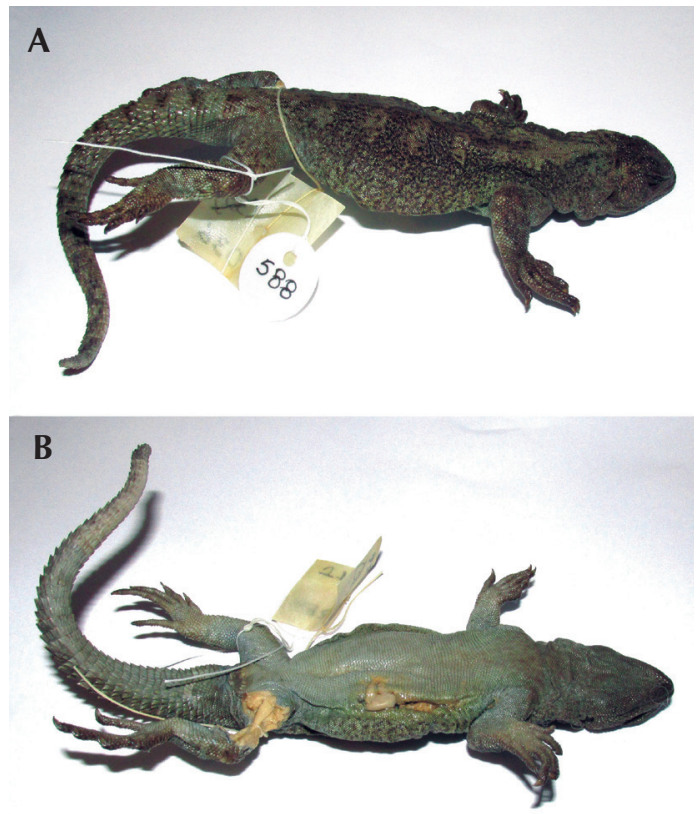

Figure 2. Holotype of Phymaturus aguedae sp. nov. $(\mathrm{SVL}=94.2 \mathrm{~mm})$ from Provincia Mountain. (A) Dorsal view. (B) Ventral view.

spots (Cei 1980), whereas male $P$. aguedae has an olive dorsal coloration with light bands. Male $P$. punae have a yellow ground color with small, dispersed dark spots and melanism on the head and neckfolds (Cei et al. 1985), whereas male $P$. aguedae have a different dorsal pattern lacking melanism on the head and neckfolds. Also, in $P$. punae, has the preocular scale larger than the canthal (Lobo et al. 2012b), whereas it is smaller than the canthal in the new species. Male $P$. antofagastensis have four or five brown markings on the head ("dice pattern") and a partially aggregated, spotted dorsal pattern without reticulation (Lobo et al. 2010). Also, in $P$. antofagastensis, the preocular scale is larger than the canthal (Lobo et al. 2012b). In P. laurenti, the male has a yellow dorsal coloration with a partially aggregated spotted dorsal pattern and enlarged postcloacal scales (Lobo et al. 2010), whereas male $P$. aguedae lack enlarged 

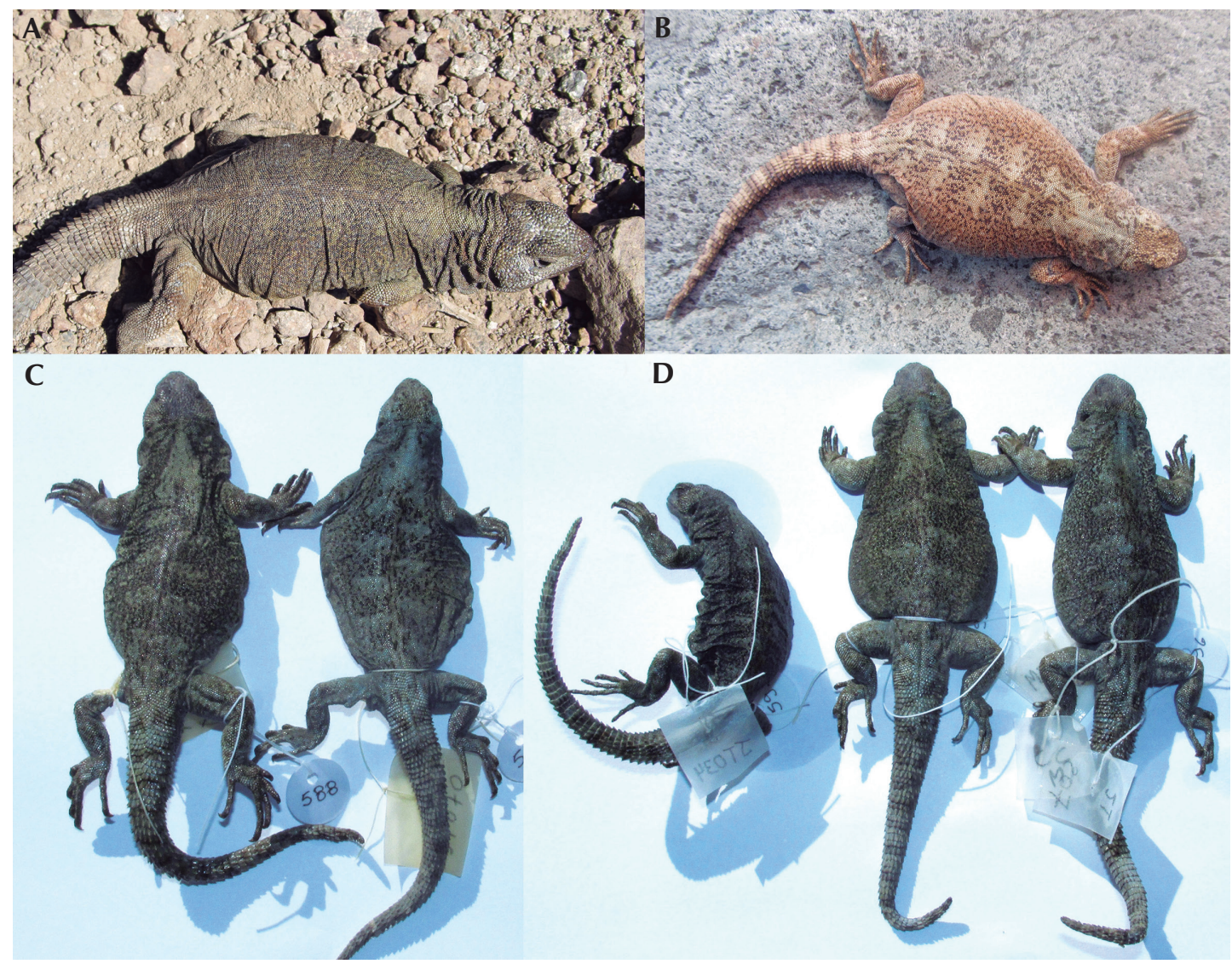

Figure 3. Variation in Phymaturus aguedae sp. nov. from Provincia Mountain. (A) Male. (B) Female. (C) Adults of the type series. Left: Holotype, male SSUC Re 588. Right: Female SSUC Re 589. (D) From left to right: Males SSUC RE 592, 595 and 596.

postcloacal scales. Phymaturus extrilidus differs in having a yellow scapular spot, gular melanism in both sexes, and the preocular scale larger than the canthal (Lobo et al. 2012c). In P. denotatus, females have small white dots dispersed on the dorsum and the sides of the neck, a unique condition among the $P$. palluma Group. Additionally, the ground color of male $P$. denotatus is yellow and the size of the preocular scale is about equal to that of the canthal (Lobo et al. 2012b). Male P. aguanegra and $P$. williamsi have head and gular melanism and lack light bands on the dorsum (Lobo et al. 2013).
The differences between Phymaturus aguedae and other Chilean species of the mallimaccii clade are as follow. The new species can be distinguished from $P$. bibronii that has posterior supralabials that project downwards; a larger preocular than canthal scale; only one subocular scale (right side); and a totally different dorsal pattern (Troncoso-Palacios et al. 2013); in contrast, $P$. aguedae lacks posterior supralabials that project downward, has a preocular scale that is smaller than the canthal, and has 4 or 5 subocular scales. Phymaturus alicahuense differs in having 1-3 suboculars, and a preocular scale 
that either is larger than, or about equal, in size to the canthal. Moreover, male $P$. alicahuense males have almost no dorsal pattern, in contrast to $P$. aguedae.

Phymaturus aguedae resembles $P$. darwini (Figure 4); however, the latter has 2-4 subocular scales $(\mathrm{x}=3.0 ; \mathrm{SD}= \pm 0.8)$, whereas $P$. aguedae has 4 or $5(\mathrm{x}=4.8 ; \mathrm{SD}= \pm 0.4)$. In $P$. darwini, the preocular is similar in size to the canthal in $72.7 \%$ of specimens and smaller than canthal in $27.3 \%$, whereas in $P$. aguedae, the preocular always is smaller than the canthal. Male and female $P$. darwini have well-defined ocelli in the paravertebral fields, whereas males and females of $P$. aguedae have diffuse light bands in the paravertebral fields and lack ocelli. Also, female $P$. darwini have a dark brown ground color and males have a dark green background color, whereas females of $P$. aguedae have light brown background coloration and males have an olive brown background color. Scalation and morphological features of geographically nearby species to $P$. aguedae is summarized in Table 1 .

Description of the holotype.- SSUC Re 588. Adult male. Measurements in mm: snout-vent length (SVL) 94.2; head length 21.4; head width 19.6; head height 11.3; interorbital distance 7.9; internasal distance 1.9; axilla-groin distance 45.7; forelimb length 32.6; hind-limb length

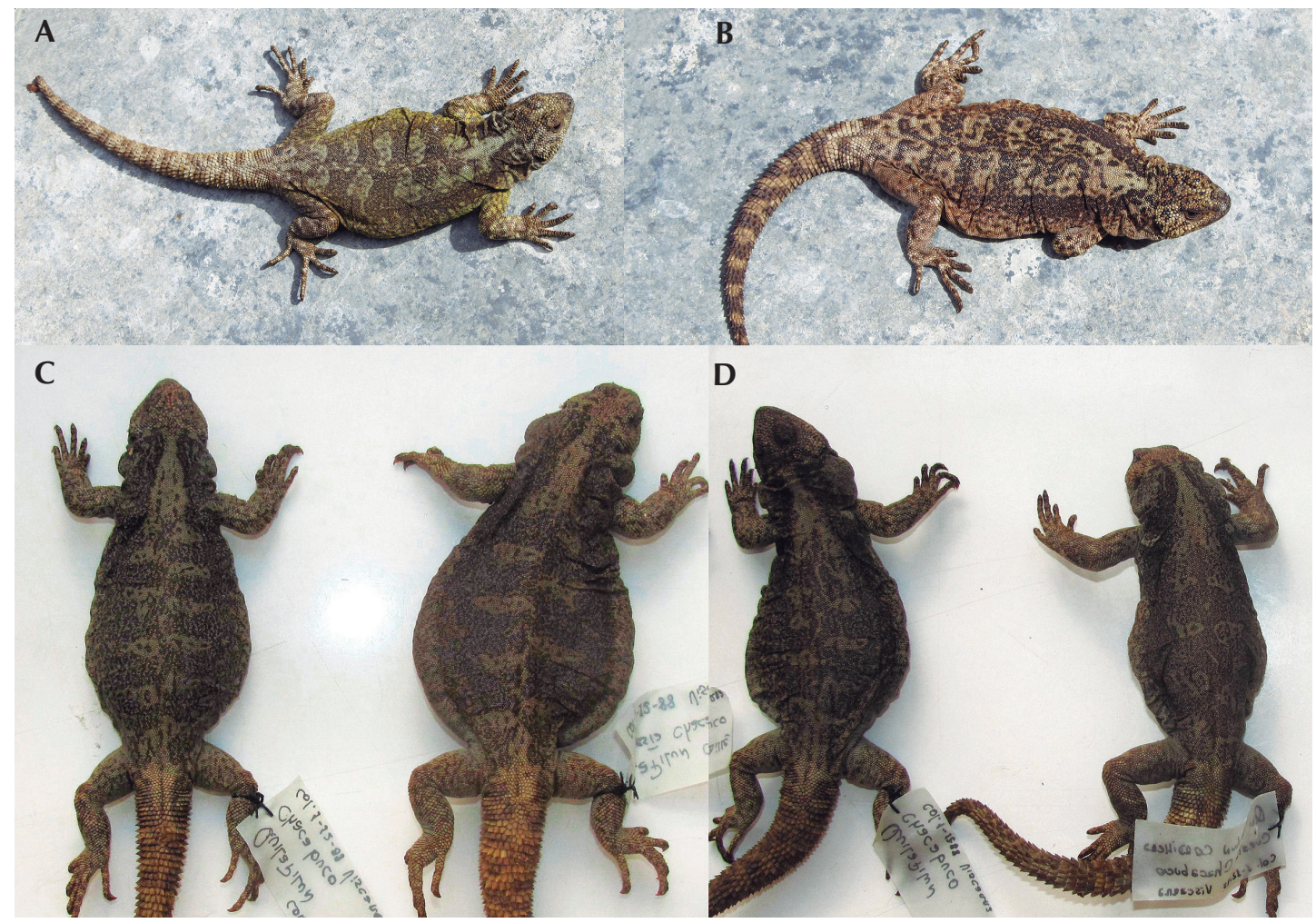

Figure 4. Variation in Phymaturus darwini. (A) Male from Carpa Mountain. (B) Female from Carpa Mountain. (C) Females from Cuesta Chacabuco (path to the Andes highlands from Cuesta Chacabuco according to $\mathrm{M}$. Lamborot). (D) Female and male from Cuesta Chacabuco (path to the Andes highlands from Cuesta Chacabuco according to M. Lamborot). 
Table 1. Scalation and morphological features of geographically nearby species to Phymaturus aguedae sp. nov. (examined juveniles are excluded). Data for $P$. extrilidus were taken from Lobo et al. (2012a). Data for $P$. williamsi were taken from Lobo et al. (2013). $\left({ }^{*}\right)$ Data taken from digital photographs of topotypes provided by A. Laspiur. $M=$ males. $F=$ females.

\begin{tabular}{|c|c|c|c|c|c|c|}
\hline & $\begin{array}{c}\text { P. aguedae } \\
\text { sp. nov. } \\
(M=4, F=1)\end{array}$ & $\begin{array}{l}\text { P. alicahuense } \\
(\mathrm{M}=5, \mathrm{~F}=2)\end{array}$ & $\begin{array}{c}\text { P. bibronii } \\
(M=8, F=9)\end{array}$ & $\begin{array}{c}\text { P. darwini } \\
(\mathrm{M}=4, \mathrm{~F}=7)\end{array}$ & P. extrilidus & P. williamsi \\
\hline $\begin{array}{l}\text { Preocular size in } \\
\text { relation to canthal }\end{array}$ & Smaller & Bigger/similar & Bigger & $\begin{array}{l}\text { Smaller/ } \\
\text { similar }\end{array}$ & Bigger & $\begin{array}{l}\text { *Bigger/ } \\
\text { similar }\end{array}$ \\
\hline $\begin{array}{l}\text { Subocular } \\
\text { fragmentation } \\
\text { (right side) }\end{array}$ & $\begin{array}{c}4 / 5(5 \text { in } \\
80 \%)\end{array}$ & $1-3$ & 1 & $\begin{array}{c}2-4(2 / 3 \text { in } \\
72.7 \%)\end{array}$ & $1-3$ & $* 1 / 2$ \\
\hline Midbody scales & $192-216$ & $204-240$ & $194-218$ & $186-232$ & $188-237$ & $185-235$ \\
\hline $\begin{array}{l}\text { Head melanism on } \\
\text { males }\end{array}$ & Absent & Absent & Absent & Absent & Present & Present \\
\hline $\begin{array}{l}\text { Dorsal pattern in } \\
\text { males (always over } \\
\text { scattered spots) }\end{array}$ & $\begin{array}{l}\text { Light triangle } \\
\text { and series of } \\
\text { light bands }\end{array}$ & $\begin{array}{l}\text { Light vertebral } \\
\text { line }\end{array}$ & $\begin{array}{l}\text { Light vertebral } \\
\text { line }\end{array}$ & $\begin{array}{l}\text { Light triangle } \\
\text { and marked } \\
\text { ocelli }\end{array}$ & $\begin{array}{c}\text { Semi } \\
\text { aggregate } \\
\text { dark } \\
\text { reticulation }\end{array}$ & $\begin{array}{c}\text { Semi } \\
\text { aggregate } \\
\text { dark } \\
\text { reticulation }\end{array}$ \\
\hline $\begin{array}{l}\text { Dorsal background } \\
\text { color in males }\end{array}$ & Olive & Brown or olive & Light brown & Dark green & $\begin{array}{c}\text { Bright to } \\
\text { pale yellow }\end{array}$ & $\begin{array}{l}\text { Brown-orange } \\
\text { to pale yellow }\end{array}$ \\
\hline Ocellus in females & Absent & Absent & $\begin{array}{l}\text { Absent / } \\
\text { Present }\end{array}$ & Present & Absent & Absent \\
\hline
\end{tabular}

50.6; right foot length 22.8; and tail length (not autotomized) 96.2. Nine scales in contact with interparietal; 16 scales between interparietal and rostral (excluding both). Parietal eye inconspicuous, whitish. Supraorbital semicircles formed by $15 / 14$ scales (left/right). Superciliary scales, 11/9 (left/right) juxtaposed and flat. Subocular scales, five on each side. Posterior subocular vertically separated from supralabials by three scales. Preocular scale smaller than canthal. Preocular and supralabials separated by six scales. Canthal separated from nasal by two scales. Nasal with nine scales in contact and separated from rostral by two scales. Rostral scale undivided. Temporal scales, 12 rhomboidal or pentagonal, slightly keeled. Three enlarged scales on the anterior border of auditory meatus.
Supralabial scales, 11; infralabial scales, 10. Pentagonal mental scale with nine scales in contact. Gular scales, 52 between the mouth's commissures (transverse count between the jaws). Well-developed antehumeral pocket. Gular fold well developed; posterior gular folds present. No enlarged scales on posterior margin of gular fold or on chest. Round, smooth, juxtaposed dorsal scales. Dorsal scales (counted between the occiput and the level of the anterior border of the hind limbs), 158. Ventral scales larger than dorsals. Hexagonal, smooth, and juxtaposed ventral scales. Ventral scales (counted from mental scale to the anterior margin of cloacal opening), 171. Scales around midbody, 206. Precloacal pores, 13. Supernumerary pores, 5 (three above and two below precloacal pores). 
No enlarged postcloacal scales. Scales of the dorsal surface of the femoral area smooth, rounded to pentagonal and juxtaposed or subimbricated. Scales of the ventral surface of the femoral area smooth, pentagonal or hexagonal, and juxtaposed. Scales of the dorsal and ventral surfaces of forearm rounded, smooth, and juxtaposed. Lamellae on the fourth toe of the right foot, 27. Tarsal scales smooth or with $2 / 3$ keels. Scales of the tail arranged in spiny annuli, slightly keeled with projected mucrons.

Color of the holotype in life.-Head light brown, with dark brown scales on snout, and supraorbital and occipital zones. Lacking melanism, head not darker than body. Dorsal ground color olive with scattered, dark brown dots. Pattern consisting of light brown triangle between the neck and shoulders (with the tip pointing toward the snout) and five series of light bands on the paravertebral fields (posterior ones fused); few dark brown dots inside lighter colored triangle and bands. Flanks with preponderance of olive scales bearing a few dark brown dots. Limbs light brown with dark brown spots. Tail light brown with 14 dark brown rings. Venter of throat gray; fore- and hind limbs light gray. Belly, cloaca, thighs, and base of the tail yellow. Venter of tail light gray, immaculate. Precloacal pores orange.

Variation.-Based on four adult males, one adult female, and two juveniles; measurements in mm. Adult males: SVL, 81.2-94.2; head length, 19.1-21.7; head width,16.9-19.7; head height, 10.3-12.0; axilla-groin distance, 34.845.7; forelimb length, 29.7-32.8; hind-limb length, 46.0-50.8 right-foot length, 21.5-22.8; and tail length (not autotomized), 80.9-96.2. Adult female: SVL, 92.3; head length, 19.4; head width,16.6; head height, 10.5; axilla-groin distance, 44.8; forelimb length, 31.5; hind-limb length, 45.6; right-foot length, 20.9; and tail length (not autotomized), 83.8.

Parietal eye inconspicuous, whitish. Superciliary scales $9-11$ on right side, juxtaposed, and flat. Subocular scales $4 / 5$ on right side; posterior subocular separated from supralabials by $2 / 3$ scales. Preocular scale smaller than canthal. Nasal separated from rostral by two scales. Rostral scale undivided, but partially divided in one specimen (SSUC Re 596). No enlarged scales on posterior margin of gular fold or on chest. Midbody scales, 192-216. In males, 1013 precloacal pores with no enlarged postcloacal scales. Lamellae on the fourth toe of the right foot, 24-28. Tarsal scales smooth or bearing 2/3 keels. Males with same color pattern as holotype, with variation in color shades. Series of dorsal light bands varying from four to five. Female with same dorsal pattern; olive scales absent and replaced by oxide-colored scales; fewer dark brown dots. Venter of throat, belly, limbs, and tail uniform light gray; tail tip light brown.

Juveniles with same pattern as males and female, but lacking olive and oxide color; smaller individual noticeably darker than adults. Two embryos with darker adult pattern.

Distribution and natural history.-Only known from the Provincia Mountain in the San Ramón Highlands (Figure 5). This mountain range comprises four mountains (from north to south)-Provincia, El Tambor, San Ramón, and Punta Damas. According to Claudio Veloso (pers. comm.), there is one record of this species from San Ramón Mountain; however, fieldwork on this mountain by L. Negrete and J. TroncosoPalacios did not yield any specimens. Phymaturus aguedae seems to be the least abundant of the Chilean congeners, given that only seven individuals were collected in four fieldtrips; two additional individuals were observed but not collected. We have visited all known populations of Chilean Phymaturus, except the type locality of $P$. darwinii, and found the other species to be more abundant. P. aguedae was found below the summit of Provincia Mountain in rocky habitats between 2683 and 2716 m elevation (Figure 6). The vegetation is composed mainly of Chuquiraga oppositifolia and Mulinum spinosum. A pair of lizards (male and female) was observed 
near a juvenile; the female had four embryos, two of which seemed to be in the final stages of development (SVLs $=39.7$ and $43.5 \mathrm{~mm}$ ), whereas the other two were undeveloped. In the intestine of one individual (SSUC Re 596), plant remnants were found but no insects. A large number of nematodes of an unidentified species were found, probably of the genus Spauligodon or Parapharyngodon (C. Garín pers. comm.). P. aguedae occurs syntopically with Liolaemus nigroviridis and L. ramonensis, even basking with both species. At the summit of Provincia Mountain, L. bellii was found, but no specimens of $P$. aguedae were observed there.

\section{Discussion}

The northern species of the Phymaturus palluma Group form a well-supported clade (Lobo and Quinteros 2005, Morando et al.
2013). Traditionally, the groups within Liolaemidae have been named based on the first species described for the group. Lobo et al. (2010) named this northern lineage the "Puna clade," because Puna refers to the northern highland region of Argentina and Chile. Morando et al. (2013) renamed it the mallimaccii group, because $P$. mallimaccii was thought to be the first species described for this clade (Cei 1980). However, the first described species of this clade is P. bibronii (Guichenot 1848), which TroncosoPalacios et al. (2013) resurrected. Nevertheless, in the interests of nomenclatural stability, we accept the name proposed by Morando et al. (2013).

Although Phymaturus aguedae was found only on the Provincia Mountain, it probably is distributed throughout the entire San Ramón Mountain range (i.e., Provincia, Tambor, San Ramón, and Punta Damas) because there are no geographical barriers (valleys) and the

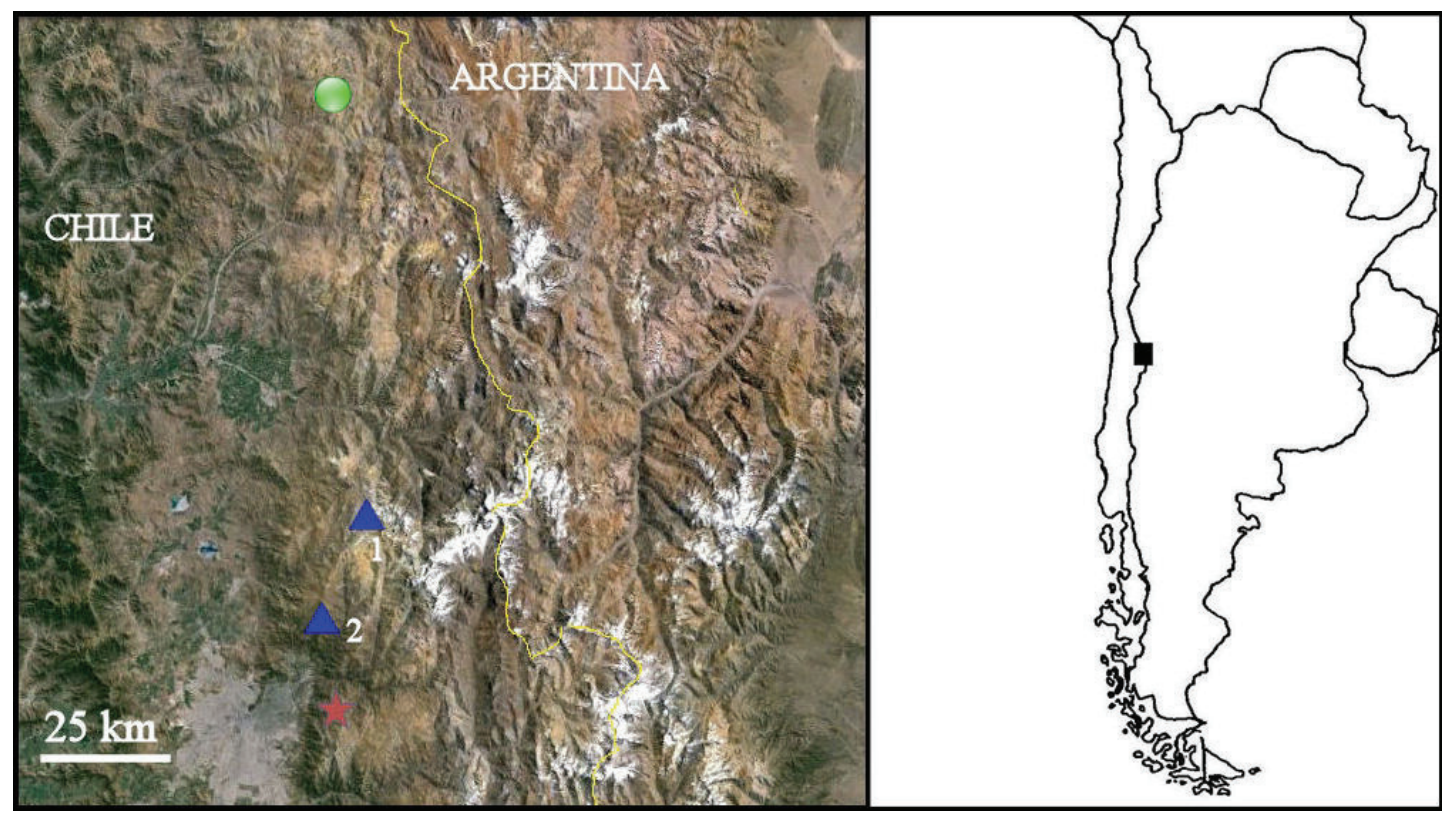

Figure 5. Distribution map for Phymaturus aguedae sp. nov. and nearby species of the mallimaccii clade. Red star: $P$. aguedae sp. nov. (Provincia Mountain, type locality). Blue triangles: P. darwini ( 1 = Riecillos, type locality; 2 = Carpa Mountain). Green circle: P. alicahuense (Quebrada de Los Piuquenes, type locality). 


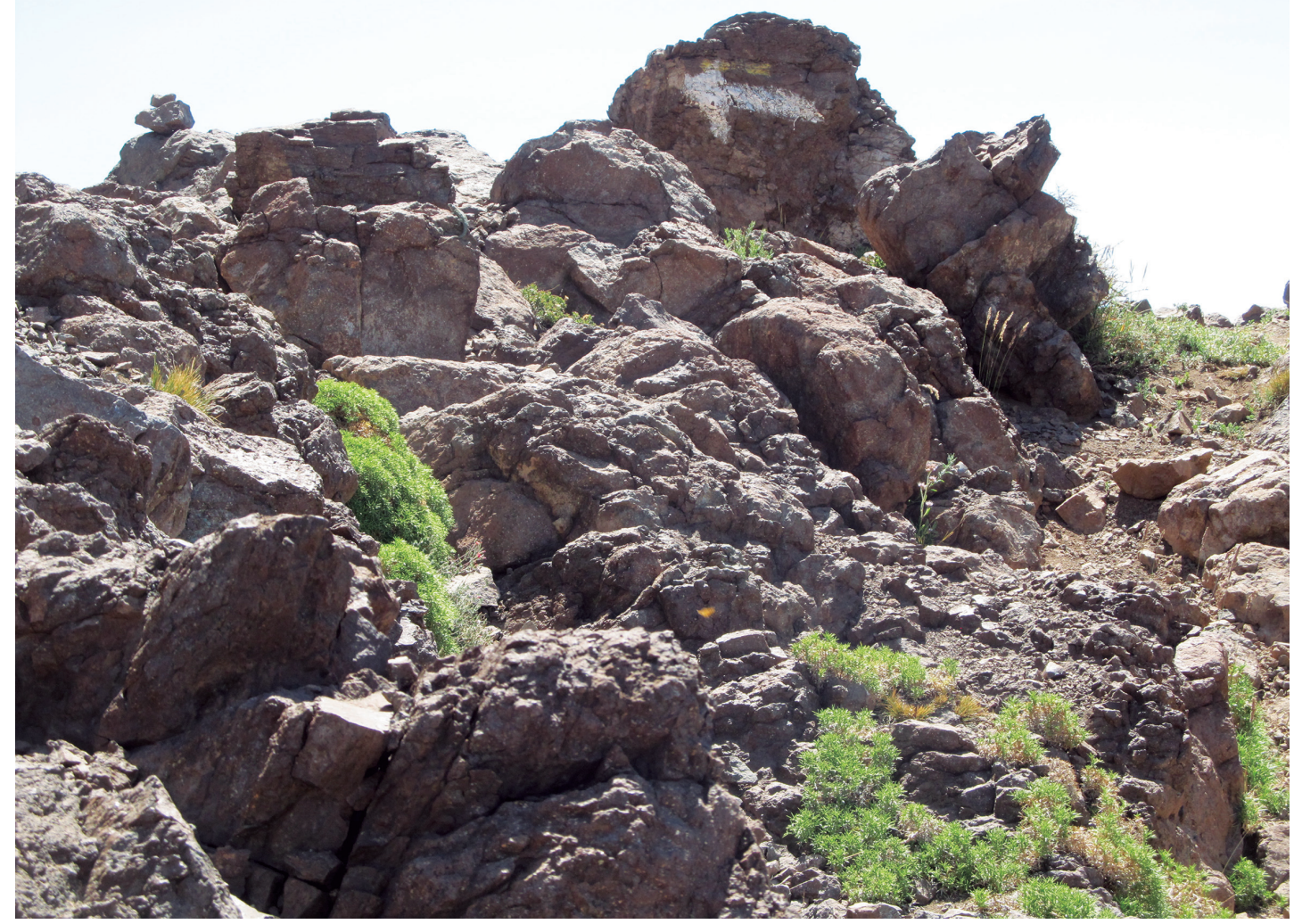

Figure 6. The habitat of Phymaturus aguedae sp. nov. in the Provincia Mountain, Metropolitan Region, Chile.

environment is homogeneous. However, given the difficulty of accessing these moutains and the low abundance of $P$. aguedae, we do not anticipate finding many more exemplars.

The similarity of the dorsal patterns of Phymaturus aguedae and $P$. darwinii are remarkable, although the ocelli are larger in $P$. darwinii. Likewise, the same trend is found in Liolaemus ramonensis and L. leopardinus, which also are endemic and co-distributed with the mentioned Phymaturus; L. leopardinus has larger ocelli than L. ramonensis (PincheiraDonoso and Núñez 2005). The occurrence of larger ocelli in $P$. darwini and $L$. leopardinus may be convergent. Perhaps these endemic lizard species from the northern highlands of the Mapocho River are subject to similar selective pressures that result in a more marked pattern than the endemic lizards that inhabit southern highlands of the Mapocho River ( $P$. aguedae and L. ramonensis).

In the description of Phymaturus darwinii, Núñez et al. (2010) reported that the male has "greenish brown dorsal background color, head without melanism, brown dorsum with diffuse pattern, a light occipital band, two diffuse dark dorsolateral bands" (our own translation). Some aspects of this description, such as "diffuse pattern" do not match our observations of the markings of $P$. darwini. We noted an obvious 
pattern consisting of a distinct triangle between the neck and shoulders, and series of ocelli in the paravertebral fields. Unfortunately, the type specimens of $P$. darwini are poorly preserved and have darkened (Figure 7); thus, we could not discern their color pattern and Núñez et al. (2010) did not provide photographs of $P$. darwini in life.

Several systematic problems involving Phymaturus in Chile are unresolved. Lobo and Quinteros (2005) reported that several populations (from El Planchón, Laguna del Maule and Termas de Chillán) might represent undescribed species. Later, Troncoso-Palacios and Lobo (2012) assigned the population of Laguna del Maule to $P$. maulense Núñez, Veloso, Espejo, Veloso, Cortes \& Araya, 2010. The population from El Planchón strongly resembles P. damasense Troncoso-Palacios \& Lobo, 2012 (Troncoso-Palacios, unpubl. data) and the population at Termas de Chillán is being examined by F. Urra and J. Troncoso-Palacios (unpubl. data).

All taxonomic studies (descriptions, synonymies and resurrections) of the genus Phymaturus are recent and ongoing in Chile (Núñez et al. 2010, Pincheira-Donoso 2004, TroncosoPalacios and Lobo 2012, Troncoso-Palacios et al. 2013). For example, P. palluma Molina, 1782, a species that was thought to be widely distributed in Chile, has been restricted to Argentina (Scolaro 2010, Lobo and Etheridge 2013). With the description of Phymaturus aguedae, the number of Chilean species increases to seven, and much remains to be learned about the ecology and behavior of these newly recognized species.

\section{Acknowledgments}

We thank M. Penna for his support, and P. Zabala (Pontificia Universidad de Católica de Chile) for allowing us to deposit material in the

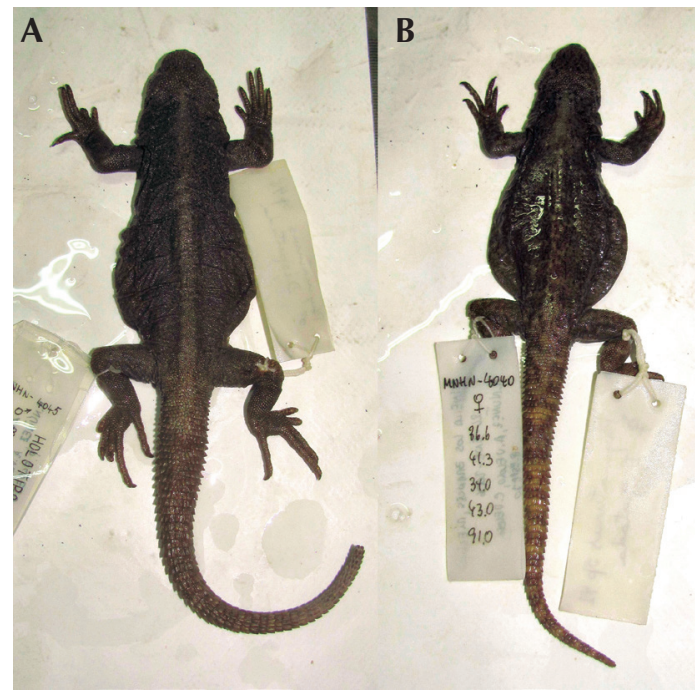

Figure 7. Some type specimens of Phymaturus darwini. (A) Holotype, male MNHN-CL 4045. (B) Paratype, female MNHN-CL 4040.

SSUC Recollection. We are grateful to the following colleagues (and museums) for allowing us to study specimens: M. Lamborot (Laboratorio de Citogenética, Facultad de Ciencias, Universidad de Chile), H. Núñez (Museo Nacional de Historia Natural de Chile). A. Laspiur, H. Núñez, R. Etheridge, and F. Lobo provided us literature, and L. Negrete, F. Meza, M. L. Carrevedo, and F. Díaz assisted us in the field. R. Martini identified the plant species and C. Garín speculated as to the possible genus of the nematodes. DE is supported by a Becas Chile-Conicyt scholarship. We thank the Servicio Agrícola y Ganadero (SAG, Chile) for authorizing the capture of specimens by permission number 0374 (2011). We thank Linda Trueb for improving the English writing and for her helpful comments. Finally, we thank A. Labra and two anonymous reviewers for improving this work. 


\section{References}

Cei, J. M. 1980. New endemic iguanid lizards from the Famatina Mountains of western Argentina. Journal of Herpetology 14: 57-64.

Cei, J. M. 1986. Reptiles del centro, centro-oeste y sur de la Argentina: Herpetofauna de las zonas áridas $y$ semiáridas. Museo Regionale di Scienze Naturali, Monografie IV, Torino 527 pp.

Cei, J. M., R. E. Etheridge, and F. Videla. 1985. Especies nuevas de iguánidos del noroeste de la provincia de San Juan (Reserva provincial San Guillermo), Argentina. Deserta 7: 316-323.

Etheridge, R. E. 1995. Redescription of Ctenoblepharys adspersa Tschudi, 1845, and the taxonomy of Liolaeminae (Reptilia: Squamata: Tropiduridae). American Museum Novitates 3142: 1-34.

Guichenot, A. 1848. Reptiles. Pp. 5-136 in C. Gay (ed.), Historia Física y Política de Chile. Volume 2. Paris. Maulde and Renou.

Lobo, F. and R. Etheridge. 2013. The type locality of Phymaturus palluma (Molina, 1782) (Reptilia: Iguania: Liolaemidae) and the status of Phymaturus adrianae Pereyra, 1992 and other unnamed populations. South American Journal of Herpetology 8: 89-101.

Lobo, F. and S. Quinteros. 2005. A morphological approach on the phylogenetic relationships within the genus Phymaturus (Iguania: Liolaemidae) with the description of four new species from Argentina. Papéis Avulsos de Zoologia 45: 143-177.

Lobo, F., C. S. Abdala, and S. Valdecantos. 2010. Taxonomic studies of the genus Phymaturus (Iguania: Liolaemidae): description of four new species. South American Journal of Herpetology 5: 102-126.

Lobo, F., C. S. Abdala, and S. Valdecantos. 2012a. Morphological diversity and phylogenetic relationships within a South-American clade of iguanian lizards (Liolaemidae: Phymaturus). Zootaxa 3315: 1-41.

Lobo, F., A. Laspiur, and J. C. Acosta. 2013. Description of new Andean species of the genus Phymaturus (Iguania: Liolaemidae) from Northwestern Argentina. Zootaxa 3683: 117-132.

Lobo, F., S. J. Nenda, and D. Slodki. 2012b. A new lizard of Phymaturus (Iguania: Liolaemidae) from Argentina. Herpetologica 68: 121-133.
Lobo, F., R. E. Espinoza, E. Sanabria, and L. Quiroga. 2012c. A new Phymaturus (Iguania: Liolaemidae) from the southern extreme of the Argentine puna. Copeia 2012: 12-22.

Morando, M., L. J. Avila, C. H. Pérez, M. A. Hawkins, and J. W. Sites Jr. 2013. A molecular phylogeny of the lizard genus Phymaturus (Squamata, Liolaemini): implications for species diversity and historical biogeography of southern South America. Molecular Phylogenetics and Evolution 66: 694-714.

Núñez, H., A. Veloso, P. Espejo, C. Veloso, A. Cortés, and S. Araya. 2010. Nuevas especies de Phymaturus (grupo palluma) para la zona Cordillerana Central de Chile (Reptilia, Sauria, Liolaemidae). Boletín del Museo Nacional de Historia Natural (Chile) 59: 41-74.

Pincheira-Donoso, D. 2004. Una nueva especie del género Phymaturus (Iguania: Tropiduridae: Liolaemini) del centro-sur de Chile. Multequina 13: 57-70.

Pincheira-Donoso, D. and H. Núñez. 2005. Las especies Chilenas del género Liolaemus Wiegmann, 1834 (Iguania: Tropiduridae: Liolaeminae): taxonomía, sistemática y evolución. Publicación Ocasional del Museo Nacional de Historia Natural (Chile) 59: 7-486.

Scolaro, J. 2010. Redescripción del neotipo de Phymaturus palluma: un aporte a la delimitación de su tierra típica (Reptilia, Sauria, Liolaemidae). Boletín del Museo Nacional de Historia Natural (Chile) 59: 29-39.

Troncoso-Palacios, J. and F. Lobo. 2012. A new species of Phymaturus (Iguania: Liolaemidae) of the palluma group from Central Chile. Cuadernos de Herpetología 26: 69-78.

Troncoso-Palacios, J., F. Lobo, R. Etheridge, J. C. Acosta, and A. Laspiur. 2013. The rediscovery of Oplurus bibronii Guichenot, 1848 a valid species of the liolaemid genus Phymaturus (Iguania: Liolaemidae). Zootaxa 3652: 547-561.

Uetz, P. 2014. The Reptile Database. Electronic database accessible at http://www.reptile-database.org. Captured on 27 May 2014.

Editor: Jaime Bertoluci 
Appendix I: Specimens examined.

Phymaturus aguedae. SSUC Re 588. Collected near the summit of the Provincia Mountain $\left(33^{\circ} 25^{\prime} \mathrm{S}-70^{\circ} 26^{\prime} \mathrm{W}\right)$, 2712 masl, Región Metropolitana, Chile. J. Troncoso-Palacios and F. Meza colls. 22/11/2011. SSUC Re 592. Near the summit of the Provincia Mountain, in the "Paso de Piedras", 2707 masl. J. Troncoso-Palacios and L. Negrete colls. November, 2009. SSUC Re 593-96. Near the summit of the Provincia Mountain, between 2683-2716 m asl. J. Troncoso-Palacios and F. Díaz colls. January, 2011. SSUC Re 589. Near to the summit of the Provincia Mountain, 2707 masl. J. Troncoso-Palacios and M.L. Carrevedo. 03/02/2012.

Phymaturus alicahuense: MNHN-CL 3820-22, 3827-28, 4104-05. Quebrada de los Piuquenes, Valparaíso Region (32016'07"S; 70²8'19"W; 2948 m). A. Veloso, C. Veloso, P. Espejo and E. Soto colls. 18-19/03/2005.

Phymaturus bibronii: SSUC Re 0428-32. Nearto Paso Los Patos, Los Molles, Ovalle, Coquimbo Region. J. Troncoso-Palacios, F. Lobo, J.C. Acosta \& A. Laspiur colls. 12/02/2011. MNHN-CL 4051-54. Los Piuquenes, Paihuano, Claro River $\left(30^{\circ} 23^{\prime}\right.$ S; 70²3'W; 3194 m). H. Núñez, A. Veloso, C. Veloso, P. Espejo and A. Cortés colls. 20/01/2006. SSUC Re 0412, 0421-27. Quebrada Los Piuquenes, Alcohuaz, Paihuano, Claro River, Coquimbo Region. TroncosoPalacios, J., F. Lobo, A. Laspiur\& J.C. Acosta Colls. 10/02/2011.

Phymaturus darwini: MNHN-CL 4040, 4042-43, 4045. Valle Riecillo, Los Bronces, Valparaíso Region, (3303'S; $70^{\circ} 22$ 'W; 3053 m). H. Núñez, A. Veloso, C. Veloso and P. Espejo colls. 26/01/2006. SSUC Re 125-27. Carpa Mountain, Metropolitan Region. J. Troncoso-Palacios and F. Meza colls. 15/11/2011. LCUC 1111a-f (six specimens). Cordillera, Quilapilun, Cuesta Chacabuco (path to the Andes highlands from Cuesta Chacabuco according to M. Lamborot). Viscarra coll. 01/12/1988. 